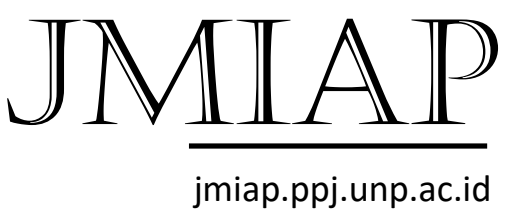

JURNAL ILMU ADMINISTRASI PUBLIK

Email : jianfis.unp@gmail.com

Vol.2 No.1 Maret 2019

\title{
IMPLEMENTASI PERWAKO PADANG NOMOR 14 TAHUN 2016 TENTANG PERATURAN PELAKSANAAN PERDA NOMOR 2 TAHUN 2015 TENTANG BANTUAN HUKUM UNTUK MASYARAKAT MISKIN
}

\author{
Mainisya Pertiwi \\ Jurusan Administrasi Publik Fakultas Ilmu Sosial Universitas Negeri Padang \\ Email : mainisyapertiwi03@gmail.com \\ Aldri Frinaldi \\ Jurusan Administrasi Publik Fakultas Ilmu Sosial Universitas Negeri Padang \\ Email : alfrinaldi@gmail.com ; aldri@ fis.unp.ac.id
}

\begin{abstract}
This research aimed to analyze the implementation Mayor Regulation of Padang Number 14 of 2016 About the Implementation of Regional Regulation Number 2 of 2015 About Legal Aid to Poor People. This was a qualitative research with normative-empiric and phenomenal approach. Informants of this research were determined with purposive sampling, that was head of subsection of legal aid and human rights of Padang City Government, Legal Aid Organizations, leaders young secretary of law Padang District Court, and poor people who received legal aid. This research used primary and secondary data derived from observation, interview, and documentation study. Validity tested of this data used source triangulation technique, and than the data were analyzed with qualitative data technique. The results of the research showed that neeed some improvement in implementation Mayor Regulation of Padang Number 14 of 2016. There are supporting factors and inhibiting factors in this regulation. Padang City Government solved the problems in this policy with some efforts.
\end{abstract}

Keywords : Implementation of Regulation, Legal Aid, The Poor People, Mayor Regulation of Padang

\section{Pendahuluan}

Diberlakukannya UU No. 16 Tahun 2011 Tentang Bantuan Hukum (UUBH) merupakan bentuk kepedulian negara terhadap warganya, yaitu dengan menjamin Hak Asasi Manusia setiap warga negaranya tanpa membedakan latar belakang termasuk kesamaan masyarakat miskin di hadapan hukum, sejalan dengan prinsip equality before the law. Dengan adanya UUBH ini, Pemerintah Daerah merasa berkewajiban untuk ikut serta dalam penyelenggaraan kegiatan bantuan hukum, maka dalam realisasinya di daerah, telah dibuat Peraturan Daerah Kota Padang No. 2 Tahun 2015 Tentang Bantuan Hukum untuk Masyarakat Miskin, yang selanjutnya peraturan ini diatur lebih lanjut dengan Perwako Padang Nomor 14 Tahun 2016 Tentang Peraturan Pelaksanaan Perda Nomor 2 Tahun 2015 Tentang Bantuan Hukum untuk Masyarakat Miskin. 


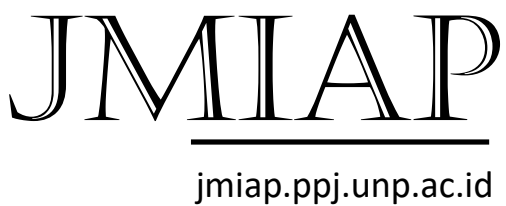

Tujuan dari diberlakukannya kebijakan ini adalah untuk menjamin keadilan yang sama bagi masyarakat yang termasuk kategori tidak mampu yang berperkara dan membutuhkan bantuan hukum untuk mendampinginya dalam berperkara, sehingga mereka mendapatkan keadilan dan perlakuan yang sama di dalam hukum. Selain itu, kebijakan ini juga sebagai implementasi dari negara hukum dan dapat menjadi pedoman dalam melaksanakan kegiatan bantuan hukum bagi masyarakat miskin.

Tahun 2015-2017 Garis Kemiskinan dan Penduduk Miskin di Kota Padang mengalami fluktuatif. Data tersebut dapat dilihat pada tabel berikut :

Tabel 1.1 Garis Kemiskinan dan Penduduk Miskin di Kota Padang tahun 2015-2017

\begin{tabular}{|c|c|c|c|}
\hline \multirow[t]{2}{*}{ Tahun } & \multirow{2}{*}{$\begin{array}{c}\text { Garis } \\
\text { Kemiskinan } \\
\text { (rupiah) }\end{array}$} & \multicolumn{2}{|c|}{ Penduduk Miskin (ribu) } \\
\hline & & Jumlah & Persentase \\
\hline 2015 & 414612 & 44,43 & 4,93 \\
\hline 2016 & 449658 & 42,56 & 4,68 \\
\hline 2017 & 482763 & 44,00 & 5,00 \\
\hline
\end{tabular}

Sumber : Kota Padang dalam Angka Tahun 2018

Berdasarkan data diatas, dapat dilihat bahwa penduduk kategori miskin di Kota Padang cukup tinggi, dimana data ini juga menjadi perhatian bahwa Kota Padang rawan terhadap tindak kejahatan, yang mana salah satu faktor orang melakukan tindak kejahatan adalah faktor ekonomi. Disinilah perlunya perlindungan terhadap masyarakat miskin yang bermasalah di hadapan hukum agar mendapatkan perlakuan yang sama di dalam hukum.

Untuk menunjang pelaksanaan kegiatan bantuan hukum di Kota Padang dan sebagai implementasi Perwako Padang No. 14 Tahun 2016, Pemko Padang telah menyediakan anggaran dan melakukan sosialisasi terkait kegiatan bantuan hukum
JURNAL ILMU ADMINISTRASI PUBLIK

Email : jianfis.unp@gmail.com

Vol.2 No.1 Maret 2019

untuk masyarakat miskin. Namun, realisasi dari pelaksanaan kegiatan bantuan hukum ini masih rendah di Kota Padang, akibatnya dana yang disediakan oleh Pemko Padang tidak terserap sepenuhnya, sebagaimana yang diungkapkan oleh Ibu Sri Hartati selaku Kepala Sub Bagian Bantuan Hukum dan HAM Pemko Padang saat dilakukan wawancara pada tanggal 19 September 2018 bahwasannya tahun 2016 Pemko Padang menganggarkan dana sebesar Rp500.000.000, realisasinya hanya 1 perkara. Kemudian di tahun 2017 Pemko Padang menganggarkan dana juga sebesar Rp500.000.000 dengan realisasinya 7 perkara. Karena dana yang dianggarkan tidak pernah terserap sepenuhnya, maka di tahun 2018 Pemko Padang menurunkan anggaran menjadi Rp224.000.000 dengan realisasi 8 perkara, yang pada perubahan anggaran di tahun 2018 tersebut anggaran kembali diturunkan menjadi Rp107.000.000. Hal ini menjadi perhatian bahwa anggaran yang seharusnya bisa digunakan semaksimal mungkin untuk melaksanakan kegiatan bantuan hukum, menjadi terus menurun akibat rendahnya realisasi pelaksanaan kegiatan bantuan hukum di Pemko Padang.Dalam hal sosialisasi yang telah dilakukan oleh Pemko Padang, masih banyak masyarakat Kota Padang yang belum mengetahui adanya kegiatan bantuan hukum yang diselenggarakan oleh Pemko Padang.Selain itu, sebagai fasilitator dan penyelenggara kegiatan bantuan hukum, Pemko Padang bekerjasama dengan Organisasi Bantuan Hukum $(\mathrm{OBH})$ terakreditasi yang terdapat di Kota Padang. OBH merasa kesulitan untuk mengakses dana bantuan hukum di Pemerintah Kota Padang karena beberapa kendala.

Berdasarkan latar belakang masalah diatas, penulis rumuskan permasalahan sebagai berikut : Pertama, bagaimanakah proses implementasi Peraturan Walikota 


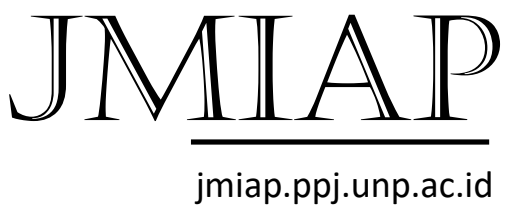

Padang Nomor 14 Tahun 2016; Kedua, apa saja faktor-faktor pendukung dan faktor penghambat dalam implementasi Peraturan Walikota Padang Nomor 14 Tahun 2016; Ketiga, apakah upaya yang dilakukan untuk mengatasi kendala dalam implementasi Peraturan Walikota Padang Nomor 14 Tahun 2016.

\section{Tinjauan Kepustakaan}

\section{Konsep Implementasi Kebijakan}

Implementasi kebijakan merupakan suatu tindakan untuk mencapai tujuan baik yang diselenggarakan oleh pemerintah maupun pihak swasta, Horn dalam(Akib \& Tarigan, 2008). Implementasi kebijakan juga merupakan tindakan-tindakan yang dibuat dan dilaksanakan oleh pemangku kepentingan untuk mencapai tujuan tertentu dan untuk menyampaikan kebijaksanaankebijaksanaan kepada masyarakat, yang didukung oleh peraturan, sumberdaya guna, dan sumberdaya keuangan. Salah satu model implementasi kebijkan yaitu model yang dikemukakan oleh Merilee S. Grindle. Grindle (Akib \& Tarigan, 2008) yang menyatakan bahwa implementasi dipengaruhi 2 aspek utama, yakni :

a. Variabel isi kebijakan

1) Kepentingan-kepentingan

kelompok sasaran : sejumlah kepentingan yang ada dalam kebijakan akan berpengaruh terhadap pelaksanaan kebijakan tersebut, karena dapat dilihat bagaimana kelompok sasaran menanggapi kepentingan tersebut.

2) Tipe manfaat : dalam kebijakan yang telah dibuat, dijelaskan tentang manfaat yang nantinya akan diterima oleh kelompok sasaran, sehingga kelompok sasaran dapat mengetahui manfaat yang diterima nantinya.
JURNAL ILMU ADMINISTRASI PUBLIK

Email : jianfis.unp@gmail.com

Vol.2 No.1 Maret 2019

3) Derajat perubahan yang diinginkan : suatu kebijakan dibuat dengan memperhatikan derajat perubahan yang diinginkan oleh pemangku kepentingan dengan adanya kebijakan tersebut.

4) Pelaksana program : untuk melaksanakan suatu kebijakan, diperlukan pelaksana kebijakan yang berkualitas dan berkompetensi untuk mendukung pelaksanaan kebijakan.

5) Sumberdaya yang dilibatkan : dengan melibatkan sumberdaya yang berkualitas dalam implementasi kebijakan, maka kebijakan tersebut dapat berjalan dengan baik.

b. Variabel lingkungan

1) Seberapa besar kekuasaan, kepentingan, dan strategi yang dimiliki oleh para aktor yang terlibat dalam implementasi kebijakan : dalam implementasi suatu kebijakan, perlu diperhitungkan besarnya kekuasaan, kepentingan, dan strategi yang digunakan untuk kelancaran implementasi.

2) Karakteristik lembaga penguasa : keberadaan lembaga penguasa di tempat pelaksanaan kebijakan menjadi salah satu faktor penentu keberhasilan mengimplementasikan kebijakan.

3) Tingkat kepatuhan dan adanya respon dari pelaksana : setelah suatu kebijakan diimplementasikan, dilihat bagaimana kepatuhan dari kelompok sasaran dan bagaimana respon pelaksana kebijakan terhadap kebijakan tersebut. 
Adapun faktor pendukung implementasi kebijakanmenurut James Anderson (dalam Darmawan, 2016) adalah : a) Adanya perhatian dan respon dari masyarakat terhadap kebijakan dan peraturan-peraturan pemerintah; b) Untuk menerima kebijakan, dibutuhkan kesadaran dari masyarakat; c) Perlunya keyakinan bahwa pemangku kepentingan membuat kebijakan tersebut dengan telah memperhatikan hal-hal penting yang telah sesuai dengan prosedur; d) Adanya sikap menerima dan melaksanakan kebijakan tersebut baik yang bersifat untuk publik maupun pribadi; dan e) Terdapat sanksi-sanksi yang telah diatur jika tidak mematuhi/tidak melaksanakan kebijakan tersebut.Kemudian faktor penghambat implementasi kebijakan menurut Bambang Sunggono dalam (Darmawan, 2016) yaitu : a) isi kebijakan; b) informasi; c) dukungan; dan d) pembagian potensi. Kemudian menurut Darwin (dalam Darmawan, 2016) aspek-aspek yang menghambat implementasi, yaitu: a) kepentingan; b) azas manfaat; c) budaya; d) aparat pelaksana; e) anggaran.

Terkait bantuan hukum, menurut Soerjono Soekanto dalam (MARBUN, 2014) adalah kegiatan memberikan keterangan dan memberikan pendampingan untuk kepentingan penerima bantuan hukum oleh pemberi bantuan hukum dalam perkara di pengadilan, pendampingan dilakukan mulai dari pemeriksaan di kepolisian hingga pembelaan di ranah pengadilan.Sedangkan menurut Adnan Buyung Nasution dalam (MARBUN, 2014) berpendapat bahwa, bantuan hukum merupakan upaya memberikan bantuan hukum untuk masyarakat yang masuk kategori tidak mampu. Dengan demikian, bantuan hukum merupakan pembelaan dan pendampingan yang diperoleh oleh penerima bantuan hukum oleh OBH tanpa biaya apapun, baik dalam melakukan pendampingan, perwakilan, pembelaan dan tindakan hukum lainnya untuk kepentingan penerima bantuan hukum baik dalam proses peradilan (litigasi) maupun di luar peradilan (non litigasi).Bantuan hukum diselenggarakan oleh Pemerintah dan dilaksanakan oleh Organisasi Bantuan Hukum $(\mathrm{OBH})$ yang terakreditasi oleh Badan Pembinaan Hukum Nasional (BPHN), dimana $\mathrm{OBH}$ adalah suatu wadah yang terorganisir dengan baik yang bertujuan untuk memberikan bantuan hukum.

Kemudian, terkait masyarakat miskin, Soerjono Soekanto dalam (MARBUN, 2014), mengatakan bahwa kemiskinan dapat diartikan sebagai keadaan dimana seseorang tidak mampu untuk memenuhi kebutuhan hidupnya baik tenaga, mental, maupun fisik. Di dalam UUBH, masyarakat miskin diartikan sebagai orang-orang yang tidak dapat memenuhi kebutuhan dasarnya secara layak dan mandiri. Ketidakmampuan secara ekonomi tersebut dibuktikan dengan Surat Keterangan Miskin dari Lurah, Kepala Desa, atau pejabat yang setingkat di tempat tinggal Pemohon Bantuan Hukum. Dengan demikian, masyarakat miskin dapat diartikan sebagai orang/sekelompok orang yang tidak mempunyai sumber mata pencaharian untuk memenuhi kebutuhan hidupnya, yang dibuktikan dengan Surat Keterangan Miskin dari pemerintah setempat.

\section{Metode Penelitian}

Penelitian ini merupakan penelitian kualitatif dengan menggunakan metode pendekatan normatif-empiris dan 


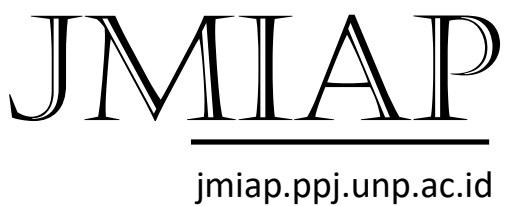

JURNAL ILMU ADMINISTRASI PUBLIK

Email : jianfis.unp@gmail.com

Vol.2 No.1 Maret 2019

fenomenal, dimana penelitian ini merupakan salah satu jenis penulisan untuk membuat gambaran serta analisis dari implementasi yang bersifat sistematis dan akurat mengenai fakta-fakta serta hubungan antara fenomena yang diteliti. Penelitian dilakukan di Pemko Padang Bagian Hukum dan di OBH yang terdapat di Kota Padang. Informan dalam penelitian ini ditentukan secara purposive sampling, yaitu Kasubag Hukum dan HAM Pemko Padang, pihak OBH, Panitera Muda Hukum Pengadilan Negeri Padang, dan masyarakat penerima bantuan hukum.

Data yang digunakan yaitu data primer dan data sekunder, yang berasal dari observasi lapangan atau pengamatan, wawancara, dan studi dokumentasi. Data ini di uji keabsahannya dengan teknik triangulasi sumber, yaitu dengan membandingkan hasil pengamatan dengan hasil wawancara. Data ini kemudian di analisis dengan teknik analisis data kualitatif mulai dari reduksi data, penyajian data, hingga penarikan simpulan.

\section{Hasil Penelitian dan Pembahasan}

Implementasi Perwako Padang No. 14 Tahun 2016 Tentang Peraturan Pelaksanaan Perda No. 2 Tahun 2015 Tentang Bantuan Hukum Untuk Masyarakat Miskin

Proses implementasi Perwako Padang No. 14 Tahun 2016 dimulai dari diberlakukannya UUBH, dimana Pemko Padang merasa berkewajiban untuk memberikan jaminan perlindungan terhadap masyarakatnya di dalam hukum, maka diberlakukan Perda Kota Padang No. 2 Tahun 2015 Tentang Bantuan Hukum Untuk Masyarakat Miskin. Dengan adanya peraturan perundang-undangan tersebut, maka Pemerintah Kota Padang mengatur

lebih lanjut pelaksanaan kegiatan bantuan hukum dengan Perwako Padang No. 14 Tahun 2016 Tentang Peraturan Pelaksanaan Perda No. 2 Tahun 2015 Tentang Bantuan Hukum untuk Masyarakat Miskin, hal ini berkaitan dengan adanya ketentuan bahwa setiap Perda yang telah dibuat, harus ada Perwako yang mengikutinya. Perwako Padang No. 14 Tahun 2016 ini kemudian ditetapkan dan diundangkan pada tanggal 14 Maret 2016. Untuk mendukung jalannya implementasi kebijakan ini, Pemko Padang melakukan beberapa upaya, diantaranya yaitu:

a. Menyediakan anggaran untuk pelaksanaan kegiatan bantuan hukum

Sejak diberlakukannya Perwako Padang No. 14 Tahun 2016, Pemko Padang menganggarkan dana untuk pelaksanaan kegiatan bantuan hukum setiap tahunnya. Hal ini sesuai dengan amanat UUBH Pasal 19 angka (1) bahwa daerah dapat mengalokasikan anggaran penyelenggaraan bantuan hukum dalam APBD, maka dalam hal ini anggaran untuk pelaksanaan kegiatan bantuan hukum disusun oleh Kepala Bagian Hukum Pemko Padang, dan selanjutnya dibahas bersama Tim Anggaran Pemerintah Daerah (TAPD), kemudian ada juga pembahasan dengan anggota DPRD, sekaligus meminta persetujuan dari anggota DPRD tersebut. Anggaran bantuan hukum akan cair jika bagian hukum sudah menyelsaikan SPJ (Surat Pertanggungjawaban) yang kemudian diserahkan ke bagian keuangan, kemudian bagian keuangan akan mengeluarkan dana.

b. Melakukan sosialisasi terkait pelaksanaan kegiatan bantuan hukum

Sosialisasi bantuan hukum dilakukan pada tahun 2016. Sosialisasi dilakukan karena belum seluruh masyarakat Kota Padang mengetahui adanya program bantuan hukum untuk masyarakat 
miskin.Pemko

Bagian sosialisasi

melaksanakan penyuluhan
Hukum dengan hukum, sosialisasi hukum, dan menyebarkan selebaran-selebaran yang berisi tentang tata cara mendapatkan bantuan hukum. Selebaran ini disebar di 11 kecamatan dan 104 kelurahan di Kota Padang.

c. Melakukan koordinasi dan kerjasama dengan pihak terkait

Koordinasi dilakukan antara Bagian Hukum Pemerintah Kota Padang dengan $\mathrm{OBH}$ dan dengan pihak terkait lainnya. Setelah diberlakukannya Perwako Padang Nomor 14 Tahun 2016, Pemko Padang Bagian Hukum memberikan informasi terkait pelaksanaan kebijakan tersebut kepada OBH sebagai petunjuk pelaksanaan kegiatan bantuan hukum, dan kepada Kelurahan serta Kecamatan di Kota Padang agar bisa di sosialisasikan kepada masyarakat setempat.

Setelah dilakukan upaya-upaya tersebut, dan melihat serta mengamati bagaimana pelaksanaan kegiatan bantuan hukum yang telah berjalan, maka Pemko Padang melakukan evaluasi terkait isi kebijakan dalam Perwako Padang No. 14 Tahun 2016 dan terkait pelaksanaan pemberian bantuan hukum. Dalam hal ini, awal tahun 2017, Pemko Padang Bagian Hukum mengeluarkan kebijakan baru terkait syarat pemohon bantuan hukum, yakni selain memiliki SKTM dan persyaratan lainnya yang telah ditentukan, pemohon bantuan hukum juga harus memiliki salah satu kartu yang dikeluarkan oleh pemerintah secara resmi seperti BPJS, dll. Hal ini dilatarbelakangi oleh adanya kelemahan dari SKTM yang dimiliki oleh pemohon bantuan hukum, diantaranya yaitu : (a) SKTM cenderung mudah untuk di dapatkan; (b) Terkadang pihak kelurahan tidak mengetahui secara pasti apakah warganya tersebut benar-benar termasuk kategori masyarakat miskin; (c) Terdapat masyarakat yang sebenarnya bukan termasuk kategori masyarakat miskin, tetapi memiliki SKTM.

Selain itu,Pemko Padang sebagai penyelenggara kegiatan bantuan hukum memiliki tanggungjawab yang besar, seperti dalam hal anggaran, dimana setiap anggaran yang dikeluarkan akan diminta pertanggungjawabannya oleh pihak terkait. Hal inilah yang menjadi pertimbangan bagi Pemko Padang untuk melakukan revisi terhadap Perwako Padang No. 14 Tahun 2016 ini, yaitu menambahkan kebijakan terkait syarat pemohon bantuan hukum dalam kebijakan ini. Selain itu, kebijakan yang belum terealisasi adalah belum adanya Tim Pengawas Daerah di Kota Padang. Di dalam Perda dan Perwako Padang terdapat kebijakan tentang Tim Pengawas Daerah, namun Kota Padang masih dalam proses pembentukan Tim Pengawas Daerah ini

\section{Faktor Pendukung dan Faktor Penghambat Implementasi Peraturan Walikota Padang Nomor 14 Tahun 2016 \\ a. Faktor Pendukung}

Faktor pendukung dari pelaksanaan Perwako No. 14 Tahun 2016 ini adalah sebagai berikut :

1) Adanya UUBH dan Perda Kota Padang No. 2 Tahun 2015 sebagai acuan

Peraturan Perundang-undangan ini menjadi pedoman dari implementasi PerwakoPadang No. 14 Tahun 2016 dan dalam pelaksanaan kegiatan bantuan hukum. Hal ini dikarenakan Perwako Padang No. 14 Tahun 2016 dibuat dengan mengacu pada UUBH, kebijakan-kebijakan yang terdapat di dalam Perwako Padang tersebut harus sesuai dengan ketentuan yang terdapat di dalam UUBH dan Perda Kota Padang. 
2) Disediakannya anggaran untuk pelaksanaan kegiatan bantuan hukum oleh Pemko Padang

Dana yang disediakan oleh Pemko Padang akan digunakan oleh $\mathrm{OBH}$ selaku pelaksana kegiatan bantuan hukum dalam menyelesaikan perkara masyarakat miskin di dalam hukum, baik untuk pendampingan perkara maupun untuk biaya transportasi, anggarannya disediakan oleh Pemko Padang, dan masyarakat miskin yang memperoleh bantuan hukum tidak membayar sedikitpun.

3) Terdapat $\mathrm{OBH}$ terakreditasi di Kota Padang

Berdasarkan KepMenHum dan HAM RI No.M.HH-01.HN.07.02 Tahun 2018 Tentang Lembaga/Organisasi Bantuan Hukum yang Lulus Verifikasi dan Akreditasi Sebagai Pemberi Bantuan Hukum Periode 2019 s.d 2021 terdapat $8 \mathrm{OBH}$ yang terakreditasi di Sumatera Barat, 4 diantaranya berlokasi di Kota Padang, 4 OBH inilah yang bekerjasama dengan Pemko Padang dalam memberikan bantuan hukum untuk masyarakat miskin.

\section{b. Faktor Penghambat}

Adapun faktor-faktor penghambat dalam implementasi PerwakoPadang No. 14 Tahun 2016 adalah sebagai berikut :

1) Terbatasnya Sumberdaya Manusia Kurangnya SDM di Pemko Padang Bagian Hukum menjadi kendala dalam pelaksanaan kegiatan bantuan hukum, karena hanya terdapat 15 orang karyawan di Bagian Hukum Pemko Padang. Jumlah ini tidak cukup untuk melaksanakan seluruh kegiatan yang terdapat di Bagian Hukum Pemko Padang, dalam pelaksanaan kegiatan bantuan hukum, diperlukan observasi ke lapangan, namun SDM yang tersedia tidak mencukupi untuk melakukan kegiatan tersebut terus-menerus, sehingga observasi ke lapangan ini tidak dilaksanakan secara baik.

2) Kurangnya pengetahuan dari masyarakat terkait implementasi Perwako Padang No. 14 Tahun 2016

Pemko Padang telah melakukan sosialisasi, penyuluhan hukum, menyebarkan selebaran, namun masih banyak masyarakat yang belum mengetahui terkait kegiatan bantuan hukum ini. Hal ini dikarenakan kurangnya budaya membaca dari masyarakat dan kurangnya komunikasi antara aparatur pemerintah seperti lurah dengan masyarakat setempat dalam memberikan informasi terkait adanya kegiatan bantuan hukum oleh Pemko Padang.

3) Terdapat beberapa kendala dari $\mathrm{OBH}$ untuk mengakses anggaran bantuan hukum di Pemko Padang

$\mathrm{OBH}$ merasa sulit untuk mengakses dana tersebut karena beberapa faktor, diantaranya yaitu : (a) Pemko Padang mengeluarkan kebijakan baru terkait syarat pemohon bantuan hukum, hal ini menjadi kendala bagi OBH karena tidak semua masyarakat miskin memiliki salah satu kartu yang dikeluarkan pemerintah tersebut; (b) KTP milik pemohon bantuan hukum harus terdaftar sebagai warga Kota Padang di Dinas Kependudukan dan Pencatatan Sipil Kota Padang; (c) Pemohon bantuan hukum harus terdaftar di Dinas Sosial Kota Padang sebagai masyarakat miskin. Karena beberapa faktor tersebut, $\mathrm{OBH}$ cenderung lebih memilih untuk mengakses anggaran bantuan hukum di BPHN atau di Pemerintah Provinsi Sumatera Barat, sehingga realisasi pelaksanaan kegiatan bantuan hukum di Pemko Padang masih rendah. 
Upaya yang dilakukan dalam mengatasi masalah dalam implementasi Peraturan Walikota Padang Nomor 14 Tahun 2016

Untuk mengatasi masalah dalam implementasi Perwako Padang No. 14 Tahun 2016, Pemko Padang melakukan beberapa upaya diantaranya yaitu :

a. Membentuk tim sadar hukum

Hal ini merupakan upaya untuk menyelesaikan masalah dalam hal terbatasnya SDM yang dimiliki oleh Pemko Padang Bagian Hukum dalam melaksanakan kegiatan bantuan hukum. Kelompok sadar hukum terdiri dari 7 orang yang rata-ratanya berisi mahasiswa dan pelajar, tenaga pekerja, swasta, dan bukan PNS. Tujuannya adalah agar memudahkan pelaksanaan pembinaan dan sosialisasi terkait bantuan hukum.

b. Melakukan revisi Perwako Padang No. 14 Tahun 2016

Hal ini merupakan upaya untuk menyelesaikan masalah dalam hal adanya kebijakan baru yang dibuat oleh Pemko Padang, namun belum tertuang dalam Perwako Padang No. 14 Tahun 2016. Kebijakan baru ini menimbulkan respon negatif dari $\mathrm{OBH}$, karena mengacu pada Perwako No. 14 Tahun 2016, tidak terdapat ketentuan mengenai kebijakan baru tersebut, maka Pemko Padang Bagian Hukummenambahkan kebijakan baru yang telah dibuat tersebut ke dalam Perwako.

\section{Pembahasan}

Sesuai dengan 2 aspek utama yang dikemukakan oleh Grindle, proses implementasi Perwako Padang No. 14 Tahun 2016 ini sudah sesuai karena dari aspek isi kebijakan, bantuan hukum dimaksudkan untuk mewujudkan jaminan keadilan bagi masyarakat miskin yang memiliki masalah hukum. Hasil penelitian ini sejalan dengan teori Grindle,

bahwasannya dari aspek isi kebijakan, kebijakan tersebut di dalamnya harus memiliki manfaat dan perubahan yang diinginkan dengan adanya suatu kebijakan. Selain itu, jika dihubungkan dengan pendapat (Frinaldi, 2017a) bahwa Kepala Daerah dapat menggunakan kewenangannya bagi kepentingan kesejahteraan sosial masyarakat di daerahnya. Dengan demikian, berdasarkan teori Grindle dan pendapat Aldri tersebut, dapat dilihat dalam penelitian ini bahwa Walikota telah berupaya menggunakan kewenangannya dalam pemberian bantuan hukum dalam bentuk Perwako Padang No. 14 Tahun 2016, dan isi dari kebijakan ini ditujukan bagi masyarakat miskin yang memiliki masalah hukum agar mendapatkan pendampingan dalam berperkara. Sedangkan dari aspek lingkungan, dikaitkan dengan teori Grindle yang yang menyatakan bahwa dari implementasi suatu kebijakan, akan ada respon dari pelaksana. Dalam hal ini, $\mathrm{OBH}$ sebagai pelaksana bantuan hukum memberikan respon terhadap adanya kebijakan baru yang dibuat oleh Pemko Padang Bagian Hukum terkait syarat pemohon bantuan hukum membuat $\mathrm{OBH}$ merasa kesulitan dalam mengakses anggaran bantuan hukum di Pemko Padang.

Adanya anggaran yang disediakan oleh Pemko Padang untuk pelaksanaan kegiatan bantuan hukum sesuai dengan pendapat Grindle dalam aspek isi kebijakan, yang menyatakan bahwa salah satu tolak ukur keberhasilan suatu implementasi adalah tersedianya sumberdaya yang dapat menunjang pelaksanaan implementasi. Kemudian, dilihat dari aspek lingkungan, adanya $\mathrm{OBH}$ terakreditasi di Kota Padang memberikan kemudahan bagi Pemko Padang untuk melaksanakan kegiatan bantuan hukum di Kota Padang. Hal ini sesuai dengan pendapat (Frinaldi, 2016) dengan adanya 


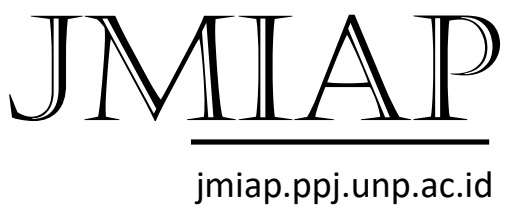

JURNAL ILMU ADMINISTRASI PUBLIK

Email : jianfis.unp@gmail.com

Vol.2 No.1 Maret 2019

koordinasi yang berkelanjutan antara pelaksana dan Pemda dengan pihak terkait terhadap kebijakan tertentu dapat menjadi salah satu upaya untuk membangun kepuasan masyarakat. Melihat kualitas dan pelayanan yang diberikan oleh $\mathrm{OBH}$ bagi masyarakat miskin, sehubungan dengan adanya kepuasan masyarakat terhadap kinerja Pemko Padang. Menurut (Frinaldi \& Embi, 2015) bahwa kepuasan masyarakat dapat dilihat dari adanya hubungan yang berpengaruh antara kualitas layanan yang diberikan oleh pelaksana dan kepuasan masyarakat sebagai penerima layanan.

Terbatasnya SDM di Pemko Padang Bagian Hukum menjadi fakto penghambat dalam melaksanakan kegiatan-kegiatan yang berkaitan dengan pelaksanaan bantuan hukum. Selain itu, adanya kebijakan baru dari Pemko Padang yang belum tertuang dalam Perwako Padang No. 14 Tahun 2016 di respon kurang baik oleh OBH dalam memberikan bantuan hukum kepada masyarakat miskin. Hasil penelitian ini sesuai dengan teori Grindle dalam aspek isi kebijakan, sumberdaya yang berkualitas merupakan salah satu faktor penunjang keberhasilan suatu implementasi kebijakan. Kemudian, dilihat dari aspek lingkungan, Pemko Padang telah melakukan sosialisasi, penyuluhan hukum, menyebarkan selebaran, namun masih banyak masyarakat yang belum mengetahui terkait kegiatan bantuan hukum ini. Hal ini dikarenakan kurangnya budaya membaca dari masyarakat dan kurangnya komunikasi antara aparatur pemerintah seperti lurah dengan masyarakat setempat,sebagaimana pendapat (Gusfi \& Frinaldi, 2018) bahwa suatu kebijakan dapat dipahami oleh masyarakat apabila dikomunikasikan, yang salah satunya dalam bentuk sosialisasi baik melalui media cetak maupun media elektronik.
Sesuai dengan teori Grindle dalam oleh Pemko Padang untuk mengatasi masalah dalam implementasi Peraturan Walikota Padang Nomor 14 Tahun 2016yaitu melakukan revisi terhadap Perwako Padang No. 14 Tahun 2016 agar kebijakan baru yang dibuat oleh Pemko Padang tertuang dalam peraturan tersebut. Kemudian dari aspek lingkungan, Pemko Padang membentuk tim sadar hukum sebagai upaya dalam mengatasi terbatasnya SDM di Pemko Padang Bagian Hukum. Dihubungkan dengan teori Grindle, bahwa kekuasaan, kepentingan, dan strategi yang dimiliki oleh aktor menjadi salah satu aspek untuk mendukung kelancaran implementasi. Hal ini sesuai dengan pendapat (Frinaldi, 2017b) bahwa budaya kerja mempengaruhi masing-masing indikator kinerja kerja secara signifikan dan juga mempengaruhi kinerja kerja secara keseluruhan.

\section{Penutup}

Perwako Padang No. 14 Tahun 2016 merupakan peraturan lebih lanjut dari UUBH dan Perda Kota Padang No. 2 Tahun 2015, yang masih memerlukan beberapa perbaikan.Dalam pelaksanaan kegiatan bantuan hukum, Pemerintah Kota Padang merupakan fasilitator dan penyelenggara dari kegiatan bantuan hukum, pemberian bantuan hukum dilaksanakan oleh Organisasi Bantuan Hukum (OBH), dan masyarakat miskin sebagai penerima bantuan hukum.

Dari aspek isi kebijakan dapat dilihat bahwa ketentuan-ketentuan yang terdapat di dalam Perwako Padang No. 14 Tahun 2016 sudah baik karena memberikan jaminan untuk masyarakat miskin agar mendapatkan keadilan di hadapan hukum, namun terdapat suatu kebijakan baru yang dikeluarkan oleh Pemko Padang Bagian Hukum yang menyebabkan OBH merasa aspek isi kebijakan, upaya yang dilakukan 


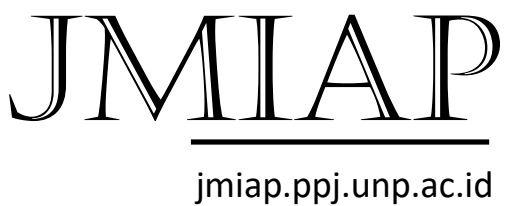

sulit untuk mengakses anggaran bantuan hukum di Pemko Padang. Kemudian, dilihat dari aspek lingkungan, Pemko Padang Bagian Hukum telah melakukan sosialisasi dan koordinasi dengan pihakpihak terkait tentang implementasi Perwako Padang No. 14 Tahun 2016, baik dengan $\mathrm{OBH}$, dengan masyarakat di Kota Padang dan melakukan sosialisasi di seluruh Kelurahan dan Kecamatan yang terdapat di Kota Padang, namun masih banyak ditemukan masyarakat yang belum mengetahui terkait adanya pelaksanaan kegiatan bantuan hukum untuk masyarakat miskin oleh Pemko Padang.Pemko Padang lebih giat lagi dalam melakukan sosialisasi terkait pelaksanaan Perwako Padang No. 14 Tahun 2016 dan pelaksanaan pemberian bantuan hukum, karena sosialisasi tersebut dilakukan oleh Pemko Padang pada tahun 2016, setelah itu sosialisasi tidak lagi dilaksanakan.

\section{Daftar Pustaka}

Akib, H., \& Tarigan, A. (2008). Artikulasi Konsep Implementasi Kebijakan : Perspektif , Model dan Kriteria Pengukurannya. Jurnal Baca, 1, 1-19.

Frinaldi, A. (2016). The Influence of Driver Work Culture and Service Quality on Citizen Satisfaction with Mass Transportation. Advances in Social Science, Education and Humanities Research, 84(Iconeg 2016), 450-453.

Frinaldi, A. (2017). The Influence Of Work Culture On Work Performance Of Employees In Department Of Transportation, Communication And Informatics Of West Sumatera. Jurnal Ilmiah Wahana Bhakti Praja, 7(2), 83-92.

Frinaldi, A. (2017b). The Use Of Freies Ermessen ( Discretion ) In Th Activity Of. Jurnal Muhammadiyah Law
JURNAL ILMU ADMINISTRASI PUBLIK

Email : ¡ianfis.unp@gmail.com

Vol.2 No.1 Maret 2019

Review, 1(1).

Frinaldi, A., \& Embi, M. A. (2015). Influence of Public Service Quality in Citizen Satisfaction Padang, West Sumatra Province ). Journal of Government and Politics, 6(1).

Gusfi, P. S., \& Frinaldi, A. (2018). The Effectiveness Of External Organization Communication On Regional Disaster Management Agency At Padang City In Implementing The Tsunami Early Warning System (Vol. 02010, pp. 48).

MARBUN, P. T. (2014). Peranan Lembaga Bantuan Hukum Dalam Memberikan Bantuan Hukum Kepada Orang Yang Tidak Mampu Setelah Diundangkannya Undang- Undang Bantuan Hukum Nomor 16 Tahun 2011.

Peraturan Walikota Padang Nomor 14 Tahun 2016. (2016). Peraturan Walikota Padang Nomor 14 Tahun 2016 Tentang Peraturan Pelaksanaan Peraturan Daerah Nomor 2 Tahun 2015 Tentang Bantuan Hukum untuk Masyarakat Miskin, 1-27. 
